\title{
EFEKTIFITAS EKSTRAK KULIT DUKU (Lansium domesticum corr) TERHADAP MORTALITAS PEDIKULUS HUMANUS CAPITIS SEBAGAI PENYEBAB PEDIKULOSIS PADA ANAK
}

\begin{abstract}
Head lice (Pediculus humanus capitis) is an insect that carries a disease that makes the loss of confidence. Efforts of control and pembutuasan head lice is the use of natural insecticides, one of the plants that have the potential as a natural insecticide is duku skin extract (Lansium domesticum Corr.). The purpose of this study was to determine mortality of head lice (Pediculus humanus capitis) and to know the compounds contained in duku skin extract. The research used laboratory experimental method with design research design post only control group. Based on the result of the research, the most effective rate of death of head louse (Pediculus humanus capitis) is $15 \%$ concentration with 4 head of head louse (80\%), while at concentration $10 \%$ is 2 tail $(40 \%)$ and at concentration 5\% there is a dead head louse $0(0 \%)$. The results of this study can be concluded that duku leaf extract (Lansium domesticum Corr.) Serves as a natural insecticide due to the presence of secondary metabolite compounds that are active in killing head lice (Pediculus humanus capitis).
\end{abstract}

Darmadi ${ }^{1)}$ Dimas Pradha SM ${ }^{2)}$ Surya Eko Setiawan ${ }^{3)}$

1,3) Akademi Analis Kesehatan Yayasan Fajar Pekanbaru

2) Universitas Abdurrab Pekanbaru

email : darmadi@univrab.ac.id

Keywords: Insecticide, Pediculus humanus capitis, Lansium domesticum Corr

\section{ABSTRAK}

Kutu kepala (Pediculus humanus capitis) merupakan serangga yang membawa penyakit yang membuat hilangnya kepercayaan diri. Upaya pengendalian dan pembrantasan kutu kepala yaitu dengan penggunaan insektisida alami, salah satu tanaman yang berpotensi sebagai insektisida alami adalah ekstrak kulit duku (Lansium domesticum Corr.). Tujuan dari penelitian ini adalah untuk mengetahui mortalitas kutu kepala (Pediculus humanus capitis) serta mengetahui senyawa yang terkandung dalam ekstrak kulit duku. Penelitian menggunakan metode eksperimental laboratory dengan desain penelitian design post only control group. Berdasarkan hasil penelitian rerata kematian kutu kepala (Pediculus humanus capitis) yang paling efektif adalah pada kosentrasi $15 \%$ dengan kematian kutu kepala sebanyak 4 ekor (80\%), sedangkan pada kosentrasi $10 \%$ sebanyak 2 ekor (40\%) dan pada kosentrasi 5\% tidak ada kutu kepala yang mati 0 ekor (0\%). Hasil penelitian ini dapat disimpulkan bahwa ekstrak kulit duku (Lansium domesticum Corr.) berfungsi sebagai insektisida alami disebabkan adanya senyawa metabolit sekunder yang aktif dalam membunuh kutu kepala (Pediculus humanus capitis).

Kata Kunci: Insektisida, Pediculus humanus capitis, Lansium domesticum Corr

\section{Pendahuluan}

Pediculosis merupakan penyakit yang disebabkan parasit yang angka kejadiannya cukup tinggi terutama pada anak sekolah.Penyakit ini telah menjadi masalah baik di negara berkembang maupun negara maju.Berdasarkan jenis kelamin, perempuan mempunyai risiko dua kali lebih besar dibandingkan dengan lakilaki.Beberapa faktor yang dapat membantu penyebaran infestasi Pediculosis adalah faktor sosial - ekonomi, tingkat pengetahuan, personal hygiene buruk, kepadatan tempat tinggal, dan karakteristik individu seperti umur, panjang rambut, dan tipe rambut (Burgress, 2009). 
Upaya pengobatan pedikulosis, terdapat beberapa produk insektisida kimia, yang biasa digunakan dalam membasmi kutu kepala.Namun penggunaan produk-produk insektisida kimia tersebut dapat menimbulkan efek samping dan tidak efektifbila tidak dilakukan secara tepat. Di Indonesia pedikulosida yang terdapat dipasaran banyak mengandung zat kimia, oleh karena itu salah satu upaya yang dapat dilakukan dalam mengurangi dampak negative akibat penggunaan pedikulosida kimia yang berlebih yaitu dengan menggunakan pedikulosida alami (Jones ddk., 2003).

Insektisida alami merupakan bahan aktif yang berasal dari tumbuhan, relatif mudah dibuat dan tidak menimbulkan dampak negatif bagi manusia maupun lingkungan sekitarnya (Isnaini, dkk, 2015). Salah satu tanaman yang memiliki potensi sebagai insektisida alami adalah buah duku, berdasarkan penelitian Mirnawaty dkk., (2012), menyatakan bahwa pemanfaatan ekstrak kulit buah duku (Lansium domesticum Corr)mampu sebagai anti nyamuk elektrik terhadap nyamuk Aedes aegipty. Senyawa yang terdapat pada kulit duku adalah flavonoid dan saponin.

Penelitian yang dilakukan oleh Virgianti dkk., (2016) menyatakan bahwa senyawa yang terkandung dalam minyak atsiri (minyak kayu putih) yang mampu membunuh Pediculus humanus capitis. Penelitian yang dilakukan oleh Fidiana dkk., (2013) bahwa ekstrak kulit duku dapat membunuh larva nyamuk Aedes aegypti pada kosentrasi $1 \%$ yaitu 11 ekor (44\%), sedangkan penelitian oleh Erviana dkk., (2014) bahwa ekstrak kulit duku dapat membunuh kecoa amerika pada konsentrasi tertinggi yaitu 100\%, didapatkan presentase mortalitas kecoa sebesar $20 \%$ pada jam ke-24 pengamatan.

Berdasarkan latar belakang yang telah dikemukakan bahwa penggunaan ekstrak kulit buah duku dapat membunuh larva Aedes aegypti dan kecoa amerika. Maka penulis tertarik ingin melakukan penelitian efektifitas ekstrak kulit buah duku (Lansium domesticum Corr) terhadap mortalitas kutu kepala (Pediculus humanus capitis) (Fidiana dkk., 2013).

\section{Tinjauan Pustaka}

\subsection{Gambaran Umum Pediculus humanus capitis}

Pediculosis merupakan infestasi kutu kepala yang disebut Pediculus humanus capitis yang menginfeksi kulit kepala.Pediculus betina akan meletakkan telur-telurnya didekat kulit kepala. Telur ini akan melekat erat pada batang rambut dengan suatu substansi yang lain. Telur akan menetas menjadi Pediculus muda dalam waktu sekitar 10 hari dan mencapai maturasinya dalam waktu 2 minggu. Penyebaran penyakit ini dapat melalui transmisi langsung kontak kepala-kepala orang yang terinfeksi. Selain itu dapat melalui transmisi tidak langsung seperti memakai sisir, topi, handuk, bantal, kasur dan kerudung yang digunakan secara bergantian (Ansyah dkk., 2013).

\subsection{Klasifikasi Pediculus humanus capitis}

Klasifikasi Pediculus humanus capitis menurut Sutanto (2008) adalah sebagai berikut:

$\begin{array}{ll}\text { Kingdom } & \text { : Animalia } \\ \text { Phylum } & \text { : Arthropoda } \\ \text { Class } & \text { : Insekta } \\ \text { Ordo } & \text { : Phthriraptera } \\ \text { Family } & \text { : Pediculidae } \\ \text { Genus } & \text { : Pediculus } \\ \text { Species } & \text { : Pediculus humanus capitis }\end{array}$




\subsection{Morfologi Pediculus humanus capitis}

Kutu rambut merupakan metemorfosis yang tidak sempurna yang terdiri dari telur $\rightarrow$ nimfa $\rightarrow$ dewasa. Pediculus humanus capitis memiliki panjang 1-3 mm, warnanya bervariasi berdasarkan warna rambut hospesnya bisa berwarna putih, keabu-abuan sampai gelap, Pediculus humanus capitis dapat bertahan selama kurang lebih 30 hari di kulit manusia sedangkan tanpa host kutu akan mati dalam waktu 1-2 hari (Bohl, 2015). Pediculus humanus capitis dewasa dapat dilihat pada Gambar 2.1

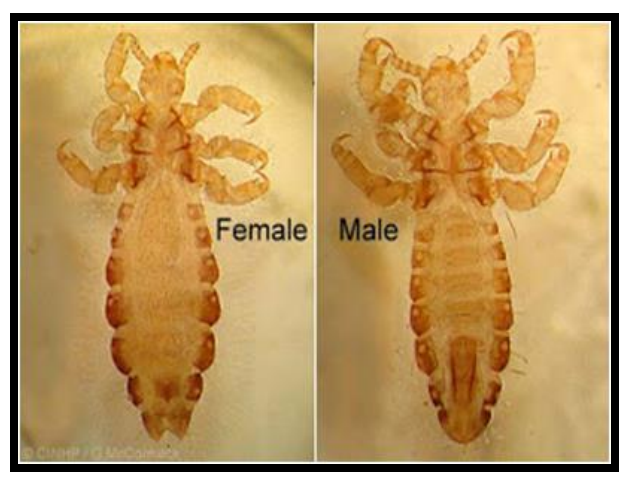

Gambar 2.1 Pediculus humanus capitis dewasa (Sumber: Ansyah dkk., 2013)

\subsection{Siklus Hidup Pediculus humanus capitis}

Siklus hidup Pediculus humanus capitis merupakan metamorfosis tidak sempurna yaitu telur - nimfa dewasa. Telur akan menetas menjadi nimfa dalam waktu 5-10 hari sesudah dikeluarkan oleh induknya. Setelah mengalami tiga kali pergantian kulit, nimfa akan mejadi kutu rambut dewasa dalam waktu 7-12 hari, dalam keadaan cukup makanan parasit ini dapat bertahan hidup 27-30 hari (Weems, 2007). Siklus hidup Pediculus humanus capitis dapat dilihat pada Gambar 2.2

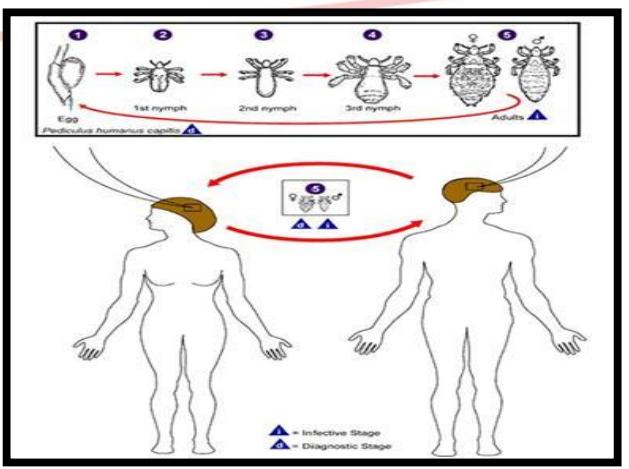

Gambar 2.2 Siklus Hidup Pediculus humanus capitis ( Sumber: Ansyah dkk., 2013) 


\subsection{Gambaran Umum Lansium domesticum Corr}

Duku merupakan salah satu tanaman berkayu yang hidup selama menahun, saat ini buah duku juga sudah menyebar luas ke berbagai belahan benua Asia terutama Asia Tenggara. Duku (Lansium domesticum Corr) juga banyak memberi manfaat bagi masyarakat, selain buahnya yang manis dan memiliki nilai gizi yang tinggi, duku juga dipercaya bagi masyarakat sebagai obat - obatan tradisional seperti penyakit disentri, diare dan malaria (Subandrate dkk., 2016).

Duku juga merupakan salah satu buah tropis, di Indonesia buah duku tersebar luas di daerah Sumatera, Kalimantan, Sulawesi dan Jawa. Buah duku mudah rusak dan berubah warna pada kulitnya menjadi kecoklatan setelah panen dalam waktu 4-5 hari, selain buahnya yang enak dan manis untuk dimakan, pada bagian kulit dan biji buah duku juga bermanfaat sebagai obat antidiare dan menurunkan demam dan pada kulit batang kayu buah duku bermanfaat sebagai obat malaria, diare dan penyembuh dari gigitan kalajengking, selain itu pada kulit dan biji buah duku banyak mengandung oleoresin yang berperan sebagai antidiare (Astawan M, 2009). Buah duku (Lansium domesticum Corr) dapat dilihat pada Gambar 2.3

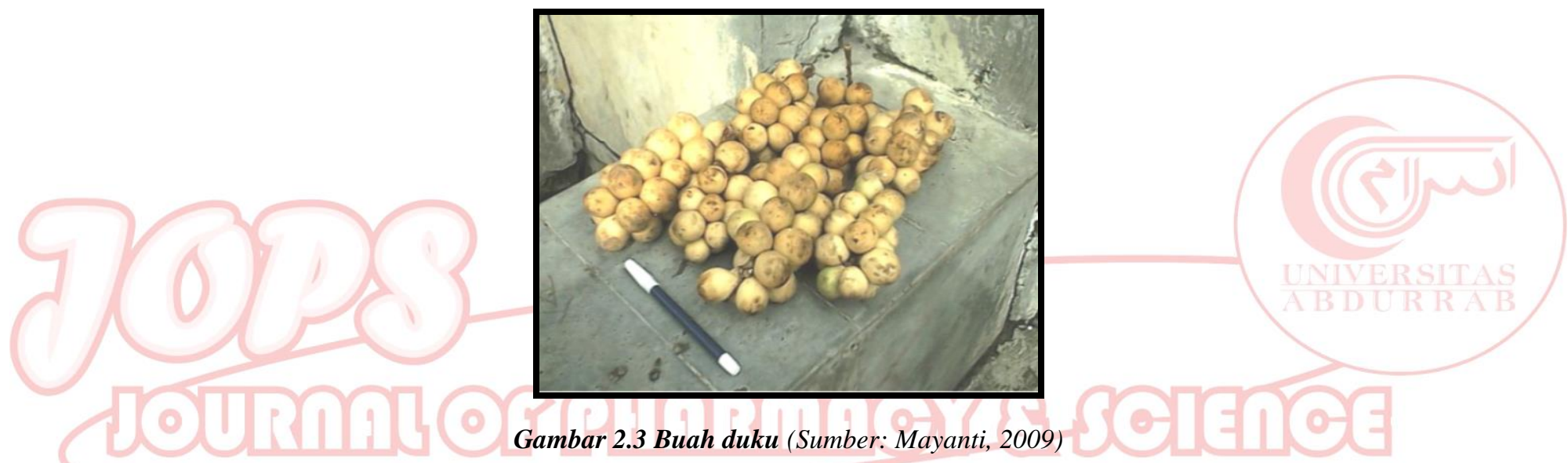

Klasifikasi Duku (Lansium domesticum Corr)

Tanaman duku (Lansium domesticum Corr) menurut Putra, WS (2013) dapat diklasifikasikan sebagai berikut:

$\begin{array}{ll}\text { Divisi } & : \text { Magnoliophyta } \\ \text { Kelas } & : \text { Magnoliopsida } \\ \text { Ordo } & : \text { Sapindales } \\ \text { Familia } & : \text { Meliaceae } \\ \text { Genus } & : \text { Lansium } \\ \text { Spesies } & : \text { Lansium domesticum Corr }\end{array}$

\section{Kandungan duku (Lansium domesticum Corr)}

Buah duku mengandung 60\% daging, sisanya merupakan biji dan kuit, pada daging buah duku banyak mengandung sukrosa, fruktosa, dan gukosa.Selain itu buah duku juga mengandung terpenoid.alkaloid, saponin, flavonoid dan polifenol. Bagian kulit buah duku bermanfaat sebagai antidiare dan menurunkan demam, pada kulit batang kayu dari tanaman buah duku juga dimanfaatkan untuk mengobati diare dan malaria.Kandungan oleoresin yang cukup tinggi terdapat pada bagian kulit dan biji tersebut sangat berperan sebagai 
antidiare.Penggunaan kulit duku juga bermanfaat sebagai mengusir nyamuk, di Filipina pembakaran kulit buah duku mampu mengusir nyamuk (Astawan, 2009).

Tabel 2.1 kandungan gizi buah duku dalam 100 gram

\begin{tabular}{ll}
\hline Kandungan Gizi & Jumlah \\
\hline Energi (kkal) & 63 \\
Protein (g) & 1,0 \\
Lemak $(\mathrm{g})$ & 0,2 \\
Karbohidrat (g) & 16,1 \\
Kalsium (mg) & 18 \\
Besi (mg) & 0,9 \\
Vitamin C (mg) & 9 \\
Vitamin B1 (mg) & 0,05 \\
Vitamin A (IU) & 0 \\
Air (g) & 80,0
\end{tabular}

Sumber : Astawan, 2009

Mayanti (2009), menyatakan bahwa setiap 100 gram buah duku mengandung air, protein, lemak, karbohidrat, gula pereduksi seperti glukosa, serat dan vitamin B1, B2, C, E. Pada kulit buah duku memiliki sifat yang toksis karena banyak mengandung tanin. Selain itu, kandungan yang terdapat pada kulit buah duku berupa terpenoid, alkaloid, saponin, flavonoid dan polifenol (Hura dkk., 2014).

\section{Metode Penelitian}

Jenis Penelitian yang digunakan adalah penelitian Eksperimental Laboratory secara in vitro, termasuk ke dalam penelitian tindakan (Action Research) yaitu penelitian yang dilakukan untuk mencari suatu pengetahuan praktis guna untuk memperbaiki suatu situasi atau keadaan kesehatan masyarakat (Notoatmodjo, 2012).

Penelitian ini dilaksanakan pada bulan juni 2017 - April 2018 di Laboratorium Mikrobiologi dan Toksikologi Akademi Analis Kesahatan (AAK) Fajar Pekanbaru. Populasi penelitian ini adalah Kutu kepala manusia (Pediculus humanus capitis ). Sedangkan sampel yang digunakan dalam penelitian ini adalah kutu kepala manusia dewasa yang diperoleh dari anak pondok pesantren yang terinfeksi oleh Pediculus humanus capitis.

\section{Prosedur penelitan}

\section{Pembuatan Ekstrak Kulit Duku}

Kulit duku yang telah disiapkan, kemudian dicuci dan lakukan pengeringan dengan caradianginanginkan, lalu dirajang kecil-kecil kemudian diblender. Sebanyak 250 gram sampel yang telah dihaluskan diekstraksi dengan cara maserasi yakni merendam sampel dalam pelarut etanol pada botol gelap selama 3 kali 24 jam. Kemudian ekstrak tersebut disaring untuk dipisahkan antara residu dan filtratnya.Lalu filtrat yang diperoleh dari perlakuan sebelumnya kemudian dimasukkan ke dalam alat evaporator untuk memisahkan ekstrak duku dengan pelarutnya.Selanjutnya menampung ekstrak kental yang diperoleh pada labu erlenmeyer.Ekstrak kental kulit duku yang telah di dapat, kemudian diencerkan untuk mendapatkan konsentrasi yaitu 5\%, 10\% dan 15\% (Minawarty dkk., 2012).

\section{Uji Fitokimia}

Sebanyak 5 gram sampel ekstrak kulit nanas ditambahkan masing-masing $5 \mathrm{~mL}$ air suling dan kloroform lalu dikocok kuat dan dibiarkan selama 8 menit sampai terbentuk dua lapisan. Lapisan air ekstrak kulit nanas digunakan untuk uji senyawa flavonoid, fenolik, dan saponin. Lapisan kloroform ekstrak kulit 
nanas digunakan untuk uji senyawa triterpenoid, dan steroid, sedangkan untuk uji alkaloid memiliki prosedur tersendiri (Harborne, 1987).

\section{Uji Flavonoid}

Beberapa tetes lapisan air ekstrak kulit nanas dimasukkan pada plat tetes lalu tambahkan $1-2$ butir logam magnesium dan beberapa tetes asam klorida pekat. Terbentuknya warna jingga, merah muda sampai merah menandakan adanya senyawa flavonoid.

\section{Uji Saponin}

Lapisan air ekstrak kulit nanas dimasukkan kedalam tabung reaksi lalu dikoocok. Apabila terbentuk busa yang bertahan selama 5 menit, menandakan positif adanya saponin.

\section{Uji Triterpenoid dan Steroid}

Lapisan kloroform ekstrak kulit nanas disaring melalui pipet yang diujungnya diberi kapas. Hasil saringan dipipet $2-3$ tetes dan dibiarkan mengering pada plat tetes. Setelah kering ditambahkan pereaksi Liebermann-Burchard (2 tetes asam asetat anhidrat dan 1 tetes asam sulfat pekat). Terbentuknya warna merah jingga menandakan bahwa positif warna hijau-biru adanya steroid.

\section{Analisis Data}

Hasil pengujian uji mortalitas kutu kepala (Pediculus humanus capitis) menggunakan ekstrak kulit duku dengan menghitung persentasi kematian kutu kepala terhadap paparan konsentrasi. Selanjutnya data yang diperoleh akan disajikan dalam bentuk tabel dan hasil percobaan di bahas secara deskriptif.

\section{Hasil Percobaan}

\section{Identifikasi Senyawa Fitokimia}

Hasil ekstraksi kulit nanas dari pelarut n-heksana, etil asetat, dan etanol dilakukan uji secara kualitatif untuk mengetahui kandungan senyawa metabolit sekunder yang ada di dalam ekstrak tersebut.Hasil identifikasi kandungan senyawa fitokimia dari ekstrak kulit nanas dapat dilihat pada Tabel 2.

Tabel 4.1 Identifikasi Fitokimia Ekstrak Kulit Duku

\begin{tabular}{lll}
\hline Senyawa & Hasil & Kesimpulan \\
\hline Flavonoid & Jingga & $(+)$ \\
Saponin & Busa bertahan selama 5 menit & $(+)$ \\
Triterpenoid & Merah jingga & $(+)$
\end{tabular}

Keterangan: Flavonoid (+) berwarna jingga sampai merah; Saponin (+) terbentuk busa yang bertahan selama 5 menit; Triterpenoid (+) berwarna merah jingga.

\section{Uji mortalitas Pediculus humanus capitis setelah pemberian ekstrak kulit duku}

Berdasarkan hasil penelitian ekstrak kulit duku (Lansium domesticum Corr.) dengan menggunakan bahan langsung terhadap mortalitas kutu kepala, maka diperoleh hasil seperti yang tercantum pada tabel sebagai berikut. 
Tabel 4.2. Hasil Mortalitas Kutu Kepala (Pediculus humanus capitis) Setelah Pemberian Ekstrak Kulit Duku (Lansium domesticum Corr.) Selama 1 Jam

\begin{tabular}{lllllll}
\hline \multirow{2}{*}{ No } & Konsentrasi & \multicolumn{2}{l}{ Mortalitas kutu kepala (ekor) } & $\begin{array}{l}\text { Rerata } \\
\text { (ekor) }\end{array}$ & $\begin{array}{l}\text { Persentase } \\
(\%)\end{array}$ \\
\cline { 3 - 6 } & I & II & III & & 0 \\
\hline 1 & $5 \%$ & 0 & 0 & 0 & 0 & 40 \\
2 & $10 \%$ & 2 & 2 & 2 & 2 & 80 \\
3 & $15 \%$ & 4 & 4 & 4 & 4 & 100 \\
4 & Kontrol (+) & 5 & 5 & 5 & 5 & 0 \\
5 & Kontrol (-) & 0 & 0 & 0 & 0 & \\
\hline
\end{tabular}

Dari tabel 4.2 diatas didapatkan mortalitas kutu kepala menggunakan ekstrak kulit duku. Kosentrasi yang paling efektif adalah 15\% dengan kematian kutu kepala sebanyak 4 ekor (80\%), sedangkan pada kosentrasi $10 \%$ sebanyak 2 ekor (40\%) dan pada kosentrasi 5\% tidak ada kutu kepala yang mati 0 ekor $(0 \%)$. Sedangkan kontrol positif (+) kematian kutu kepala sebanyak 5 ekor (100\%), sedangkan kontrol negatif (-) tidak ada kutu kepala yang mati 0 ekor $(0 \%)$.

\section{Pembahasan}

Kulit duku yang telah dihaluskan digunakan untuk proses maserasi dengan menggunakan pelarut metanol. Proses maserasi menurut Istiqomah (2013) dapat menarik zat-zat atau bahan kandungan dari tanaman untuk larut dalam suatu pelarut tertentu. Selain itu, proses maserasi ini sangat sederhana karena tidak memerlukan alat-alat yang rumit dan hanya dilakukan dengan cara merendam bahan tanaman ke dalam suatu pelarut selama waktu tertentu. Filtrat dari hasil maserasi diuapkan dengan rotary vacum evaporator sehingga dihasilkan ekstrak metanol.Pengguapan dengan menggunakan rotary vacum evaporator menurut Arudhina., dkk (2012) bertujuan untuk memisahkan pelarut dengan senyawa fitokimia yang terkandung di dalam kulit duku tersebut.

Hasil uji fitokimia dengan menggunakan ekstrak kulit duku diperoleh senyawafitokimia yaitu senyawa flavonoid yang ditandai dengan adanya perubahan warna jingga sampai merah, senyawa saponin ditandai dengan terbentuknya busa yang bertahan selama lima menit, sedangkan senyawa triterpenoid ditandai dengan adanya perubahan warna sampai merah jingga

Pengujian yang dilakukan untuk mengetahui mortalitas kutu kepala (Pediculus humanus capitis) dengan ekstrak kulit duku (Lansium domesticum Corr.) yang dilakukan selama 1 jam pada konsentrasi 5\%, $10 \%$ dan 15\%. Kematian kutu kepala (Pediculus humanus capitis) tergantung variasi konsentrasi, artinya besar kecilnya konsentrasi ekstrak kulit duku (Lansium domesticum Corr.) yang diberikan sangat berpengaruh terhadap mortalitas kutu kepala (Pediculus humanus capitis).Semakin tinggi tingkat kepekatan suatu bahan kimia maka semakin banyak senyawa metabolit sekunder yang terkandung dalam ekstrak kulit duku (Lansium domesticum Corr.), sehingga semakin efektif daya bunuhnya (Kapsara dan Akhmadi, 2016).

Kutu kepala (Pediculus humanus capitis) yang mati pada pengujian ini terjadi karena bahan yang diteteskan.Bahan yang diteteskan adalah ekstrak kulit duku (Lansium domesticum Corr.) yang mengandung senyawa metabolit sekunder didalamnya yaitu flavonoid, saponin dan triterpenoid. Senyawa metabolit 
sekunder yang terdapat pada ekstrak kulit duku (Lansium domesticum Corr.) merupakan racun kontak yang masuk kedalam tubuh kutu kepala (Pediculus humanus capitis) secara langsung (Yuliana dkk., 2016).

Mekanisme masuknya flavanoid kedalam tubuh serangga yaitu melalui sistem pernafasan berupa spirakel yang terdapat dipermukaan tubuh dan menimbulkan kelemasan pada saraf serta terdapat kerusakan pada spirakel yang mengakibatkan serangga tidak dapat bernapas dan akhirnya mengalami kematian. Saponin masuk melalui dinding tubuh serangga dan bersifat racun yang mengakibatkan kematian terhadap serangga (Yuliana dkk., 2016). Triterpenoid bersifat sebagai repellent (penolak), juga mampu menurunkan enzim yang terdapat pada pencernaan dan penyerapan makanan bila dikonsumsi serangga (Widawati dan Prasetyowati.,2013).

Hasil metabolit sekunder yang diperoleh dari ekstrak kulit duku (Lansium domesticum Corr.), diduga adanya kandungan senyawa metabolit sekunder yang terdapat pada ekstrak kulit duku memiliki kemampuan dalam membunuh kutu kepala (Pediculus humanus capitis), yang mempengaruhi sistem saraf, keseimbangan hormon, menghambat sistem reproduksi, anti-makan dan kerusakan pada sistem pernafasan serangga (Ridhwan dan Isharyanto., 2016).

Serangga mampu mendeteksi rangsangan melalui alat sensornya yang disebut olfaktori yang bersifat kimia (aroma), sehingga serangga tersebut akan merespon untuk mendekat yang bersifat menarik (attractant) atau menjauh dari sumber rangsangan tersebut apabila dianggap membahayakan bagi serangga tersebut (Sari dkk., 2016).

Penelitianyuliani dan juliani (2017)., menyatakan bahwa flavonoid merupakan senyawa yang bertindak sebagai stomach poisoning atau racun perut, sehingga apabila flavonoid masuk ke dalam tubuh serangga maka sistem pencernaannya akan terganggu, senyawa tersebut juga mampu menghambat reseptor perasa pada daerah mulut serangga, sehingga menyebabkan serangga tidak mampu mengenali makanannya, hingga mati kelaparan.

Penelitian ini juga diperkuat oleh Ni'mah dkk (2014)., menyatakan bahwa buah duku juga memiliki senyawa sebagai larvasida yaitu flavonoid karena mampu menghambat sintesa asam nukleat (DNA) dan pernafasan pada larva. Saponin memiliki aktivitas anti makan (antifeedant) dan menghambat pertumbuhan larva dan merusak membran yang menyebabkan kematian.

Pemaparan ekstrak metanol kulit duku pada perlakuan konsentrasi 5\%, 10\% dan 15\% menyebabkan knockdown pada Pediculus humanus capitis. Terjadinya knockdown pertama memiliki perbedaan waktu yang berbeda pada masing-masing perlakuan. Perlakuan ekstrak kulit dukukonsentrasi $15 \%$ menyebabkan knockdown dan kematian dalam waktu 1 jam, konsentrasi 10\% juga mampu menyebabkan knockdown dan kematian pada kutu kepala dalam waktu 1 jam, sedangkan untuk konsentrasi 5\% membutuhkan waktu yang lama untuk memberikan pengaruh knockdown dan kematian pada kutu kepala (Pediculus humanus capitis) dibandingkan konsentrasi 10\% dan 15\% yaitu dalam waktu 27 menit (Kumalasari dkk., 2015).

Pada masing-masing perlakuan memberikan efek paling baik dalam membunuh kutu kepala dengan variasi waktu yang berbeda. Kontrol positif sangat efektif membunuh kutu kepala dalam waktu 50 menit, hal ini dikarenakan bahan kimia yang terkandung didadalam kontrol positif mampu membunuh kutu kepala . Sedangkan untuk kontrol negatif tidak menimbulkan efek terhadap kutu kepala, hal ini disebabkan tidak adanya bahan kimia yang terdapat pada kontrol negatif.

\section{Kesimpulan}

Berdasarkan hasil penelitian tentang uji mortalitas Pediculus humanus capitis menggunakan ekstrak kulit duku (Lansium domesticum Corr..) dapat disimpulkan : 
1. Terbukti bahwa ekstrak kulit duku (Lansium domesticum Corr..) berfungsi sebagai insektisida alami. Konsentrasi 5\% tidak dapat membunuh kutu kepala (Pediculus humanus capitis), konsentrasi 10\% dapat membunuh kutu kepala (Pediculus humanus capitis) dengan persentasi $40 \%$ dan konsentrasi 15\% dapat membunuh kutu kepala (Pediculus humanus capitis) dengan persentasi $80 \%$. Percobaan dilakukan dalam waktu 1 jam.

2. Diketahui di dalam ekstrak kulit duku (Lansium domesticum Corr..) terdapat senyawa metabolit sekunder yaitu flavonoid, saponin dan triterpenoid.

\section{REFERENSI}

1. Ansyah, A. N., Pramuningtyas, R., dan Kariosentono, H. 2013. Hubungan Personal Hygiene dengan Angka Kejadian Pedikulosis Capitis pada Santri Putri Pondok Pesantren Modern Islam Assalaam Surakarta.[Skripsi]. Surakarta: Fakultas Kedokteran Universitas Muhamidayah Surakarta.

2. Astawan, M. 2009. Sei kesehatan keluarga sehat dengan buah. Dian Rakyat Jakarta.

3. Burgress, I. F. 2009.Current Treatments for Pediculosis Capitis. Curr Opin Infect Dis. 22(6)

4. Bohl, B. 2015.Clinical Practice Update: Pediculosis Capitis. Pediatric Nursing, 41(5):227-34.

5. Erviana, R dan Nukmal, N. 2014. Uji Potensi Kulit Buah Duku (Lansium domesticum) Terhadap Mortalitas Kecoa Amerika (Periplaneta americana) Dewasa. Bandar Lampung. FMIPA Universitas Lampung. Halaman $308-315$.

6. Fidiana, D. F., Mifbakhuddin dan Nurullita, U. 2013. Daya Bunuh Ekstrak Kulit Duku (Lansium domesticum Corr.)Terhadap Kematian Larva Aedes aegypti. Jurnal Kesehatan Masyarakat Indonesia. 8 (2): Halaman 22-29.

7. Greive, K. A., dan Barnes, T. M. 2012. In Vitro Comparison of Four Treatments Which Discourage Infestation by Head Lice, Parasitol Res. 110:16951699.

8. Hura, R. S. R., Suhatri., Elisma dan Vahrozi, H. 2014. Uji Aktivitas Antidiare Ekstrak Kulit Buah Duku (Lansium membranaceum (Kosterm.) Mabb) Pada Mencit Putih Jantan.Prosiding Seminar Nasional dan Workshop "Perkembangan Terkini Sains Farmasi dan Klinik IV". Padang.

9. Isnaini, M., Pane, E, R., dan Wiridianti, S. 2015. Pengujian Beberapa Jenis Insektisida Nabati Terhadap Kutu Beras (Sitophilus oryzae L). Jurnal Biota. 1 (1): Halaman 1 - 8.

10. Jones, K. M dan English Iii, J.G. 2003.Review Of Common Theurapeutic Options In The United Sates For The Treatment Of Pediculosis Capitis. Clinical Infections Deases. 36: 1355-61.

11. Kamiabi, F dan Nakhaei, F. H. 2005.Prevalence of Pediculosis Capitis and Determination of Risk Factors in Primary School Children in Kerman. EastMediterr Health J. 11(5):988-92.

12. Kardinan, A. 2003.Tanaman Pengusir dan pembasmi Nyamuk. Argomedia pustaka. Jakarta

13. Lailatul, L. K., Kadarohman. A., dan Ratnaningsih, E. 2010.Efektivitas Biolarvasida Ekstrak Etanol Limbah Penyulingan Minyak Akar Wangi (Vetiveria zizanoides) Terhadap Larva Nyamuk Aedes aegypti, Cules sp, dan Anopheles sundaicus.Jurnal Sains dan Teknologi Kimia. Volume (1)1:

14. Leung, A. K., Fong, J. H., dan Rojas, A. P. 2005. Pediculosis Capitis.J Pediatr HealthCare.19(6):369-73.

15. Mayanti, T. 2009. Kandungan Kimia dan Bioaktivitas Tanaman Duku. Unpad Press. Bandung.

16. Minarwaty, Supriadi dan Jaya, B. 2012. Uji Efektifitas Ekstrak Kulit Langsat (Lansium domesticum Corr.) Sebagai Anti Nyamuk Elektrik Terhadap Nyamuk Aedes aegypti. Jurnal Akademika Kimia. 1 (4): Halaman 147-52.

17. Natadisastra, D., dan Ridad, A. 2009.Parasitologi Kedokteran. Jakarta: Penerbit EGC. Halaman.8296.

18. Notoadmojo, S. 2010. Metodologi Penelitian Kesehatan. Rineka Cipta. Jakarta.

19. Putra, W. S. 2013. 68 Buah Ajaib Penangkal Penyakit.Ar- Ruzz Media. Yogyakarta 
20. Pritacindy, A, P ., Supriyadi., dan Kurniawan, A. 2013. Uji Efektifitas Ekstrak Bawang Putih (Allium sativum) Sebagai Insektisida Terhadap Kutu Rambut (Pediculus humanus capitis). Universitas Negeri Malang. Malang. Jurnal Kesehatan. Halaman 1-9.

21. Salim, M., Sulisityaningrum, N., Isnawati, A., Sitorus, H., Yahya dan Ni'mah, T. 2016.Karakteristik Simplisia dan Ekstrak Kulit Buah Duku (Lansium domesticum Corr.) dari Provinsi Sumatera Selatan dan Jambi.Jurnal Kefarmasian Indonesia. 6 (2): Halaman 117-128.

22. Subandrate., Sinulingga, S., Wahyuni, S., Altiyan, M, F dan Fatmawati. 2016. Potensi Antioksidan Ekstrak Biji Duku (Lansium domesticum Corr.) Pada Tikus Putih (Rattus novergicus) Jantan Yang Diinduksi Alkohol. Molekul. 11 (1): Halaman 1-8.

23. Sutanto. 2008. Buku Ajar Parasitologi Kedokteran : Edisi Keempat. Jakarta.

24. Virgianti, D. P., dan Rahmah, L. A. 2016. Efektifitas Beberapa Merk Minyak Kayu Putih Terhadap Mortalitas Pediculus humanus capitis Secara In Vitro. Jurnal Kesehatan. Vol.15 No.1. Halaman 1-9.

25. Weems, H. V., dan Fasullo, T. R. 2007. Human Lice: Body Louse, Pediculus humanus humanus Linnaeus and Head Louse. IFAS Extension.10(4):1-5.

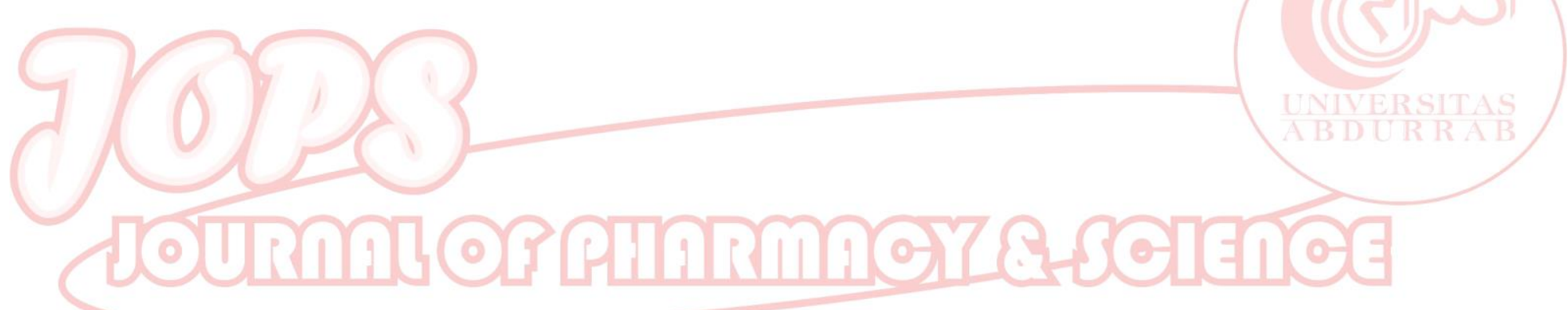

